\title{
THE PROHIBITION OF ALCOHOL REVISITED: THE US CASE IN INTERNATIONAL PERSPECTIVE
}

\section{by Ruth DUPRÉ}

Cahier de recherche $n^{\circ}$ IEA-04-11

OCTOBER 2004

ISSN : 0825-8643

Copyright (C) 2004. HEC Montréal.

Tous droits réservés pour tous pays. Toute traduction ou toute reproduction sous quelque forme que ce soit est interdite.

Les textes publiés dans la série des Cahiers de recherche HEC n'engagent que la responsabilité de leurs auteurs.

La publication de ce Cahier de recherche a été rendue possible grâce à des subventions d'aide à la publication et à la diffusion de la recherche provenant des fonds de HEC Montréal.

Direction de la recherche, HEC Montréal, 3000, chemin de la Côte-Sainte-Catherine, Montréal (Québec) Canada H3T 2 A7. 


\section{ABSTRACT}

The 13-year American episode of the prohibition of alcohol (1919-1933) is so notorious and has been so extensively studied that there would not seem to be much to add. However, very little of this work has been done in a comparative and international perspective. Yet, the prohibition movement was international and quite a few countries, particularly the ones with a significant Anglo-Saxon Protestant majority, went through a long lasting and vigorous struggle over the issue. While some of them came quite close to a total ban, they finally adopted different regimes and none went as far as the U.S. Why was it? This is the question addressed in this paper. Using a political economy approach, we try to compare the strength and stakes of the supporters and opponents of prohibition in the U.S., Canada, Australia and New Zealand. As these countries shared many socio-cultural features with the US, this international exploration should shed new light on the American experiment with prohibition, an episode which has always been somehow a paradox in the land of individual freedom and minimalist government.

\section{RÉSUMÉ}

L'épisode de la prohibition aux États-Unis (1919-1933) est tellement célèbre et a fait l'objet de tant d'études qu'on pourrait se demander ce qu'on peut bien y ajouter. Toutefois, très peu de ces recherches ont été effectuées dans une perspective comparative et internationale. Or, le mouvement prohibitionniste était international et un bon nombre de pays, particulièrement ceux à majorité anglo-saxonne protestante, ont vécu des épisodes de controverses vigoureuses sur la question de la prohibition. Alors que certains d'entre eux sont venus bien près de l'abolition totale, ils ont finalement adopté des régimes différents et aucun n'est allé aussi loin que les États-Unis. Pourquoi ? C'est la question examinée dans ce texte. Au moyen d'une approche de «public choice», nous tentons de comparer les forces et enjeux des partisans et des opposants à la prohibition aux États-Unis, Canada, Australie et Nouvelle-Zélande. Comme ces pays partageaient d'importantes caractéristiques socioculturelles avec les États-Unis, cette comparaison devrait jeter un nouvel éclairage sur l'expérience américaine de la prohibition, un épisode qui a toujours été un paradoxe dans cette terre championne de la liberté individuelle et du gouvernement minimaliste. 


\section{INTRODUCTION}

«After one year from the ratification of this article the manufacture, sale, or transportation of intoxicating liquors within, the importation thereof into, or the exportation thereof from the United States and all territory subject to the jurisdiction thereof for beverage purposes is hereby prohibited».

Article XVIII, Section 1, Constitution of the United States.

The $18^{\text {th }}$ Amendment, the only constitutional attempt to incorporate a sumptuary restriction into the fundamental law, launched the United States in one of the most curious, colourful and controversial episode of its history. In the land of individual freedom and minimalist government, this extreme form of government intervention into regulating people behavior has always been somehow a paradox.

The 13-year US prohibition of alcohol (1920-1933) fascinated generations of historians who filled thousand of pages narrating the regional and local experiences, the temperance organizations and personalities. ${ }^{1}$ There is also a substantial literature from sociology and

\footnotetext{
${ }^{1}$ Witness the 13 pages of bibliography in the recent study by Szymanski (2003: 302-214) listing all the regional and local histories of prohibition in the US. Not a single American state, I think, is left unexplored.
} 
political science. Studies and books keep coming out ever since the 1920s. Economists are much less numerous to be interested in this topic. And those who are, with the exception of a handful of public choice articles, are more concerned with the impact of prohibition than with its causes. ${ }^{2}$

In spite of such abundance, there should be room for another way to look at the phenomenon as very little -if any- of this work has been done in a comparative and international perspective. ${ }^{3}$ Yet, the prohibition movement was international and quite a few countries, particularly the ones with a significant Anglo-Saxon Protestant majority, went through a long lasting and vigorous struggle over the issue. While some came quite close to a total ban, they finally adopted different regimes and none went as far as the U.S. Why was it? This is the question addressed in this paper by comparing the US case to Canada, Australia and New Zealand. As the four countries shared so many socio-cultural features (immigrant countries, Anglo-Saxon and Protestant culture) this international exploration should shed new light on the American experiment with prohibition.

Next section summarizes the main features of the history of the prohibition issue in the four countries. Then, section 3 outlines the model we wish to use and explores the differences between the four countries regarding the major factors behind the choice of prohibition as

2 Jeffrey Miron $(1991 ; 2001)$ produced a set of rigorous studies on the impact of the alcohol prohibition of the $1920 \mathrm{~s}$ as a historical experiment to analyze prohibition of drugs policies. Thornton (1991)'s book is also of interest. The few public choice empirical studies we were able to find are Goff and Anderson (1994); Munger and Schaller (1997) and Hersch and Netter (1989). The first two contrast the support for prohibition in 1917 (Congressional votes) to the repeal in 1933 while the third is concerned with the timing of adoption of statewide prohibition before 1919. There are also some public choice studies of votes in specific states such as Missouri and California in 1918 (Wasserman 1989 and 1990).

${ }^{3}$ There are of course a few exceptions: for instance, Tyrell (1991) on the WCTU around the world or Paulson (1973) comparing prohibition and women suffrage in Scandinavia, U.S., and Australia. 
policy. The task is ambitious and we are in the first stage of the project which is why the paper contains more questions than answers.

\section{The Road to Prohibition: A Century of Temperance Struggle in Comparative Perspective}

The story of the temperance movement struggle to suppress the liquor trade is usually divided into four phases: the 1840s-50s, the 1870s-80s, the 1890s-First World War and the 1920s. The first two were quite similar in the four countries of our concern, the main difference being that the movement seems to have been more timid and the results obtained more modest in Australia. After the beginning of the $20^{\text {th }}$ century, the roads began to diverge as numerous states and provinces adopted prohibition in North America while none was able to in Australasia, even though New Zealand came quite close. But it is after World War I that the roads split into three branches: the U.S. went for total national prohibition, Canada after some provincial experiments with sale prohibition- chose state ownership and Australia and New Zealand continued with their licensing and regulating systems.

\section{Taking the Pledge: The Beginnings of the Temperance Movement, 1840s-1850s.}

In the four countries, pioneer days of late $18^{\text {th }}$, early $19^{\text {th }}$ century were days of heavy drinking. Alcohol consumed was mostly in the form of «ardent spirits» like rum and whisky, which according to the data available were consumed in a much larger volume than today by 
the male population. ${ }^{4}$ The temperance movement arose out of concerns that this behaviour was evil for the individual and disruptive for society. At both levels, the movement was focused on salvation. In the US, the first temperance societies were established in Massachusetts in the 1810s, in Canada in the 1820s and in Australasia in the 1830s. In each country, they were led by Protestant, especially the Evangelical denominations as part of the revivalism and in the US the Second Great Awakening.

From the 1840 s, a number of organizations and societies, most of them originating from the United States, crossed to Canada and eventually to other English Colonies such as Australia and New Zealand. The most notable were, in chronological order, the Washingtonians (1840-49), the Sons of Temperance (formed in 1842 in the US, spread to Canada in 1847) and the Order of Good Templars (set up in 1850 in the US, 1855 in Canada, 1868 in Britain and the $1870 \mathrm{~s}$ in Australasia). ${ }^{5}$

One of out ten Americans (1.5 million) took the abstinence pledge. Abstinence pledges were also very popular across British North American colonies and were present in the Australasian colonies. As early as 1851, Maine was the first state to adopt prohibition. A number of American states (12) and the Canadian province of New Brunswick (then a British Colony) followed Maine in the 1850s. With the Civil War, all bans except a handful were repealed. ${ }^{6}$

\footnotetext{
${ }^{4}$ See for instance, Noel (1995), Smart and Ogborne (1996) for Canada; Rorabaugh (1979) for the US, Reeves (1902) for Australasia. Water was dangerous, tea and coffee expensive and the times and work to accomplish were hard.

${ }^{5}$ In Australia, the beginnings seem to have been more timid. One of the stories reported by Reeves (1902:305) is revealing. He writes that Richard Heales, afterwards the Prime Minister of Victoria, never missed the weekly meeting of the Melbourne Total Abstinence Society, though occasionally he seems to have been the only member present.

${ }^{6}$ By end of the 1870s, seemingly were only left Maine, Vermont and New Hampshire.
} 


\section{Drying up the Countryside: Women's Crusades and Local Option Laws, 1870s-1880s}

The revival of the temperance movement was aimed at saloons, beer and foreigners in the cities. It began in the U.S. with the creation of the Prohibition Party in 1869 and with the notorious women's temperance crusades of 1873-4 in which thousands of women kneeled, sang and prayed in front of saloons all over the country but mostly in the Midwest. ${ }^{7}$ This led to the formation of a new organization, quite important in the women's movement, the WCTU (Women Christian Temperance Union) in 1874 in the U.S. and in Canada. A decade later, it was international (the WWCTU) and active in Australia and in New Zealand.

Even if the ultimate goal of the WCTU and other temperance organizations was nationwide prohibition, the main policy they fought for and obtained in that second wave were the socalled local option bills. Through this type of legislation, higher level governments (state or provincial; in Canada, federal and provincial) allowed local (county, city or township) bans on sales of alcoholic beverages following a poll taken at given intervals after a specified proportion of the population signed for it. They were widespread in the Anglo-Saxon world. Our four countries were at that time under some local option laws. As Table 1 shows, there was a variety in the forms and rules the local options could take. Particularly noteworthy is the case of Australia where most of the local options were limited to vetoing new licenses. Very few allowed drying up a unit and when they did, it came rather late (beginning of the $20^{\text {th }}$ century) and required a $3 / 5$ majority. As a result, almost no dry areas were to be found

\footnotetext{
${ }^{7}$ Morone (2003) gives a number as high as 100 000. Some women did more, like the infamous Carrie Nation who broke in saloons and bars with a hatchet, but mostly they demonstrated peacefully in front of the saloons.
} 
in Australia, a situation quite different from the North American one as can be seen in Tables 2 and 3.

TABLE 1

Forms of Local Option in Australia and New Zealand (as compared to Canada and the U.S.)

\begin{tabular}{|c|c|c|c|}
\hline & [1] & [2] & [3] \\
\hline Australia & As of 1900 & As of 1912 & As of 1928 \\
\hline New South Wales & $\begin{array}{l}\text { 1882: limited (veto } \\
\text { on new licenses) }\end{array}$ & $\begin{array}{l}\text { 1906: full } \quad(3 \\
\text { questions*; } 3 / 5 \\
\text { majority; held day of } \\
\text { general elections) }\end{array}$ & $\begin{array}{l}1919 \text { amendment } \\
\text { suspends the local } \\
\text { option } \\
\text { pending } \\
\text { referendum on state } \\
\text { prohibition } \\
\text { compensation; } 1923 \\
\text { amendment fixes the } \\
\text { date to Sept 1928. }\end{array}$ \\
\hline Victoria & $\begin{array}{l}\text { 1885: limited (can } \\
\text { increase or reduce up } \\
\text { to a statutory limit) }\end{array}$ & $\begin{array}{llr}\text { 1906: no } & \text { new } \\
\text { licenses unless } 3 / 5 \\
\text { wants it; full }(3 \\
\text { questions*) by Jan. } \\
1917 .\end{array}$ & $\begin{array}{l}1922 \text { Act abolishes } \\
\text { local option system } \\
\text { to replace it by a } \\
\text { vote on no license } \\
\text { every } 8^{\text {th }} \text { year, first in } \\
1930 \text {. }\end{array}$ \\
\hline Queensland & $\begin{array}{l}\text { Full (and no new } \\
\text { licenses unless } 3 / 5 \\
\text { wants it) }\end{array}$ & $\begin{array}{l}\text { 1912: «progressive» } \\
\text { prohibition: } 1 \\
\text { question: reduce by } \\
25 \% \text { every general } \\
\text { election }(1916,1919, \\
1922,1925) \text { If } \\
\text { successful, in } 1925 \\
\text { number of licenses } \\
\text { reduced to } 0 .\end{array}$ & $\begin{array}{l}\text { Minor amendments } \\
\text { in } 1920,1923,1926 \\
\text { on areas and dates. }\end{array}$ \\
\hline South Australia & $\begin{array}{l}\text { 1876: limited (veto } \\
\text { new licenses); 1891: } \\
\text { can reduce the } \\
\text { number } \\
\text { compensation with }\end{array}$ & $\begin{array}{l}\text { 1908: still only } \\
\text { power to reduce the } \\
\text { number }\end{array}$ & $\begin{array}{l}\text { 1917: local option } \\
\text { poll held on day of } \\
\text { general election }\end{array}$ \\
\hline Tasmania & $\begin{array}{l}\text { No local option law } \\
\text { (ratepayers right to } \\
\text { petition) }\end{array}$ & $\begin{array}{l}\text { 1908 act: full 1.o. by } \\
1 / 1 / 1917\end{array}$ & $\rightarrow$ \\
\hline West Australia & $\begin{array}{l}\text { No local option. } \\
\text { Right to protest } \\
\text { against new licenses }\end{array}$ & $\begin{array}{l}\text { Still no local option. } \\
\text { Bill introduced in } \\
1912 \text { did not pass. }\end{array}$ & $\begin{array}{l}1922 \text { amendment to } \\
\text { licensing act: set up a } \\
\text { Reduction Board; } \\
\text { 1925: every } 5^{\text {th }} \text { year } \\
\text { poll on prohibition } \\
\text { no compensation. }\end{array}$ \\
\hline
\end{tabular}




\begin{tabular}{||l|l|l||}
\hline & \multicolumn{1}{|c|}{ [1] } & \multicolumn{1}{|c|}{ [2] } \\
\hline \hline New Zealand & \multicolumn{1}{|c|}{ As of 1900 } & \multicolumn{1}{c|}{ As 1912 } \\
\hline \hline & $\begin{array}{l}\text { 1881: full (3 questions*: first } \\
\text { 2 require simple majority; } 3^{\text {rd }} \\
\text { no license majority of 3/5; } \\
\text { ratepayers' votes; triennial at } \\
\text { day of general elections) }\end{array}$ & $\begin{array}{l}\text { After } 1894 \quad 1^{\text {st }} \text { poll, } \\
\text { amendment to let vote all } \\
\text { citizens (men and women). } \\
1910 \quad \text { Act: repealed local } \\
\text { option system to replace it by } \\
2 \text { ballots: yes or no to no } \\
\text { license and yes or no to } \\
\text { national prohibition }\end{array}$ \\
\hline
\end{tabular}

\section{Canada}

Full (yes or no to retail sales in a given unit -city, county, township-; $1 / 4$ electors must ask for a poll, requires simple majority to win (except in Ontario local opt. law 3/5 majority); exception for medicinal, sacramental and industrial uses

1864 Dunkin Act for the Province of Canada before Confederation (i.e. Ontario and Quebec); 1879 Canada Temperance Act (Scott Act) by the federal government; some provinces like Ontario (1890) add their own local option act. The judiciary decided that federal and provincial governments had concurrent powers on local option laws.

\section{United States}

Wide variety of local option rules (different units: city, township, or larger scale: county; different percentage required for getting a poll, etc) but all were full, that is could abolish licenses in a given area. Almost all states had local option laws. We found only two without:

New Jersey and Nevada by 1912.

Sources: [1] Reeves (1902, 1969: 306-315)

[2] Hayler (1913: 311-318 and 325-330)

[3] Australia Yearbook (1928: 1001-1004)

Notes: $\quad * 3$ questions $=$ continuance, reduction of number of licenses or no licenses (local prohibition). 
TABLE 2

Local Option in Action:

Dry Areas in Australia, New Zealand and Canada

\begin{tabular}{||l|c|c||}
\hline \multicolumn{1}{|c|}{ Australia } & As of 1900 & As of 1912 \\
\hline \hline New South Wales & & 0 \\
\hline Victoria & 0 & 0 \\
\hline Queensland & 1 (Mildura) & «many new districts» \\
\hline South Australia & 0 & 0 \\
\hline Tasmania & $\begin{array}{c}\text { 1 (township no name } \\
\text { mentioned) }\end{array}$ & 0 \\
\hline Western Australia & 0 & 12 \\
\hline \hline \multicolumn{1}{|c|}{ New Zealand } & 0 & 1 (Clutha) \\
\hline
\end{tabular}

\begin{tabular}{|l|l|l|l||}
\hline \multicolumn{1}{|c|}{ Canada } & \multicolumn{1}{|c|}{ By 1878 } & \multicolumn{1}{|c|}{$\begin{array}{c}\text { After Scott Act } \\
\text { (1879) }\end{array}$} & \multicolumn{1}{c|}{ By 1913 } \\
\hline \hline Ontario & $\begin{array}{l}\text { Dry everywhere } \\
\text { except big cities } \\
\text { (Toronto, Ottawa, } \\
\text { Kingston) }\end{array}$ & $\begin{array}{l}\text { (out of 69 } \\
\text { counties with polls) }\end{array}$ & $\begin{array}{l}169 \text { with 3/5 } \\
\text { majority + 164 with } \\
\text { simple majority out } \\
\text { of 440 contest polls } \\
\text { from 1909 to 1913. }\end{array}$ \\
\hline Quebec & $\begin{array}{l}\text { Very few votes: 3 } \\
\text { dry }\end{array}$ & $\begin{array}{l}8 \text { (out of 17 counties } \\
\text { with polls) }\end{array}$ & About 30 \\
\hline Maritime Provinces & $\begin{array}{l}\text { Prohibition in New } \\
\text { Brunswick; 2 others } \\
\text { local option }\end{array}$ & $\begin{array}{l}\text { (out of 47 } \\
\text { countries with polls) }\end{array}$ & Nearly all \\
\hline $\begin{array}{l}\text { Manitoba, } \\
\text { B. Columbia }\end{array}$ & ---- & $\begin{array}{l}\text { Manitoba: 2 (out of 2 } \\
\text { with polls) }\end{array}$ & \\
\hline \hline
\end{tabular}

Sources: For Australia and New Zealand, Reeves (1902:320) and Hayler (1913:311-318 and 323-330). For Canada, Smart (1996:42) and Hayler (1913:251-266). 
TABLE 3

Population Living in Dry Areas in the U.S. in 1911 (in 000s)

\begin{tabular}{|c|c|c|c|}
\hline State & Living in dry areas & Total population & $\begin{array}{c}\% \text { living in dry } \\
\text { areas }\end{array}$ \\
\hline New England & 2499 & 6627 & $38 \%$ \\
\hline$\overline{\text { Connecticut }}$ & 200 & $\overline{1115}$ & $\overline{18}$ \\
\hline Maine & 742 & 742 & 100 \\
\hline Massachusetts & 1062 & 3366 & 32 \\
\hline New Hampshire & 239 & 431 & 55 \\
\hline Rhode Island & 17 & 543 & 3 \\
\hline Vermont & 239 & 430 & 56 \\
\hline Eastern & $\underline{2753}$ & $\underline{21215}$ & $\underline{13 \%}$ \\
\hline$\overline{\text { Dist. Washington }}$ & 59 & 331 & $\overline{18}$ \\
\hline Delaware & 79 & 202 & 39 \\
\hline Maryland & 450 & 1295 & 35 \\
\hline New Jersey & 138 & 2537 & 5 \\
\hline New York & 647 & 9185 & 7 \\
\hline Pennsylvania & 1380 & 7665 & 18 \\
\hline Middle & $\underline{14545}$ & $\underline{29889}$ & $\underline{49 \%}$ \\
\hline Illinois & 1900 & 5639 & 34 \\
\hline Indiana & 1756 & 2701 & 65 \\
\hline Iowa & 1719 & 2225 & 77 \\
\hline Kansas & 1691 & 1691 & 100 \\
\hline Michigan & 750 & 2810 & 27 \\
\hline Minnesota & 1060 & 2076 & 51 \\
\hline Missouri & 1211 & 3293 & 37 \\
\hline Nebraska & 595 & 1192 & 50 \\
\hline North Dakota & 577 & 577 & 100 \\
\hline Ohio & 2300 & 4767 & 48 \\
\hline South Dakota & 400 & 584 & 68 \\
\hline Wisconsin & 586 & 2334 & 25 \\
\hline Southern & $\underline{23940}$ & $\underline{27560}$ & $\underline{87 \%}$ \\
\hline$\overline{\text { Alabama }}$ & 1924 & 2138 & 90 \\
\hline Arkansas & 1435 & 1574 & 91 \\
\hline Florida & 658 & 753 & 87 \\
\hline Georgia & 2609 & 2609 & 100 \\
\hline Kentucky & 1721 & 2290 & 75 \\
\hline Louisiana & 850 & 1656 & 51 \\
\hline Mississippi & 1797 & 1797 & 100 \\
\hline North Carolina & 2206 & 2206 & 100 \\
\hline Oklahoma & 1657 & 1657 & 100 \\
\hline South Carolina & 1100 & 1515 & 73 \\
\hline Tennessee & 2185 & 2185 & 100 \\
\hline
\end{tabular}




\begin{tabular}{|lrrc||}
\hline \hline Texas & 3409 & 3897 & 87 \\
Virginia & 1500 & 2062 & 73 \\
West Virginia & 889 & 1221 & 73 \\
Western & $\mathbf{1 7 1 6}$ & $\underline{\mathbf{6 2 2 7}}$ & $\mathbf{2 5 \%}$ \\
\hline Arizona & 45 & 204 & 22 \\
California & 600 & 798 & 25 \\
Colorado & 436 & 326 & 55 \\
Idaho & 217 & 376 & 67 \\
Montana & 15 & 82 & 4 \\
Nevada & 8 & 327 & 10 \\
New Mexico & 40 & 673 & 12 \\
Oregon & 230 & 374 & 34 \\
Utah & 125 & 1142 & 42 \\
Washington & 481 & 146 & 34 \\
Wyoming & 50 & & $\mathbf{4 9 \%}$ \\
TOTAL U.S. & & $\mathbf{9 2 1 1 8}$ & \\
\hline
\end{tabular}

Source: Hayler (1913:275-294) president of the International Prohibition Confederation. For his comparative international study, he uses the material supplied by the national temperance organizations, the Anti-Saloon League for the U.S.

Pushing for Prohibition: Pressure Groups, Plebiscites, and Regional Bans, 1890s-WWI

In this period, the outcomes began to diverge between the two continents. In North America, especially in the U.S., the increasingly aggressive Drys scored many victories. In 1895, the leadership of the temperance movement shifted from the larger purposed reformist organizations («do-everything») like the WCTU to the ASL (the Anti-Saloon League), a single-issue («get rid of the saloon») organization, a model of a modern lobbying group with a sharp strategy of intimidating politicians to vote dry. ${ }^{8}$ Table 3 above shows how dry were the US at the end of the first decade of the $20^{\text {th }}$ century. By $1911,49 \%$ of the population was

\footnotetext{
${ }^{8}$ One of the strategy of the ASL was to ask politicians to sign this kind of pledge: «Are you willing to announce yourself as in accord with the crystallised public sentiment which seeks the destruction of the liquor traffic?». in Hayler (1913:281).
} 
living in dry areas with important regional differences: $87 \%$ of the population in the Southern states, $13 \%$ of the population in the Eastern states. In the $1910 \mathrm{~s}$, the movement intensified as 24 states turned to statewide prohibition between 1914 and 1919 to reach a total of 33 before the big victory of the $19^{\text {th }}$ Amendment.

In Canada, the temperance movement led by the umbrella organization, the Dominion Alliance for the Total Suppression of the Liquor Trade, was pushing very hard on the federal government to get a national plebiscite, encouraged by the results in the four provincial referenda of 1892 (see table 4). It finally took place in 1898: with a low turn out of $44 \%$, the results were extremely close: $51 \%$ yes with Quebec strongly against ( $81 \%$ no). Afraid to split the country and to pass a legislation impossible to enforce, P.M. Laurier decided not to act upon those results. Defeated at the federal level, the prohibitionists turned to the provinces. They succeeded only in the smallest of them, Prince Edward Island in 1902. Large scale prohibition would have to wait for the First World War.

The New Zealand Alliance (created in 1886) was able to finally obtain from the government a law allowing national prohibition plebiscites at every general election. The first was held in 1911 and prohibition obtained a majority at $56 \%$ but not the $3 / 5$ required. Afterwards, all the other referendums never reached more than 49\% (see table 4). In Australia, the temperance movement was unable to get a state referendum even less a legislation on prohibition before WWI. Each of the six states formed under the new federation in 1901 kept its own alcohol policy of licensing regulations and local options (table 1, column 2). 
TABLE 4

National or Regional Referenda on prohibition of alcohol:

U.S., Canada, New Zealand, Australia

1880-1930

\begin{tabular}{|c|c|c|c|c|}
\hline Year & United States & Canada & $\begin{array}{c}\text { New } \\
\text { Zealand }\end{array}$ & Australia \\
\hline 1880 & Kansas $(52 \% \mathrm{Y})$ & & & \\
\hline 1881 & North Carolina & & & \\
\hline 1882 & Iowa & & & \\
\hline 1883 & Ohio & & & \\
\hline 1884 & Maine $(75 \% \mathrm{Y})$ & & & \\
\hline 1886 & Rhode Island & & & \\
\hline 1887 & $\begin{array}{l}\text { Michigan., Texas, } \\
\text { Tennessee., Oregon }\end{array}$ & & & \\
\hline 1888 & West Virginia & & & \\
\hline 1889 & $\begin{array}{l}\text { New Hampshire. Massachusetts, } \\
\text { Pennsylvania., N. Dakota } \\
(52 \% \text { Y }) \text { S. Dakota, Washington, } \\
\text { Connecticut. }\end{array}$ & & & \\
\hline 1890 & Nebraska & & & \\
\hline 1892 & & Manitoba $(74 \% Y)$ & & \\
\hline 1893 & & $\begin{array}{l}\text { P. Edward Island } \\
(79 \% \mathrm{Y})\end{array}$ & & \\
\hline 1894 & & $\begin{array}{l}\text { N. Scotia }(79 \% \mathrm{Y}) \text {, } \\
\text { Ontario }(63 \% \mathrm{Y})\end{array}$ & & \\
\hline 1898 & & $\begin{array}{l}\text { Canada }(51 \% \mathrm{Y}) / \\
\text { regional } \\
\text { breakdown: Ontario } \\
(57 \% \mathrm{Y}) ; \\
\text { Quebec }(19 \% \mathrm{Y}) ; \\
\text { Maritimes }(82 \% \mathrm{Y}) \text {; } \\
\text { West }(69 \% \mathrm{Y})\end{array}$ & & \\
\hline 1902 & & $\begin{array}{l}\text { Ontario }(66 \% \mathrm{Y}) \\
\text { Manitoba }\end{array}$ & & \\
\hline 1903 & Vermont (W) & & & \\
\hline 1907 & Oklahoma $(54 \% \mathrm{Y})$ & & & \\
\hline 1908 & N. Carolina $(62 \% \mathrm{Y})$ & & & \\
\hline 1909 & Alabama $(\mathrm{W})$ & & & \\
\hline 1910 & $\begin{array}{l}\text { Florida + Oregon + Missouri. } \\
\text { (W); Oklahoma. (D) }\end{array}$ & & & \\
\hline 1911 & $\begin{array}{l}\text { Maine }(50,3 \% \mathrm{Y}) \\
\text { Texas }(49 \% \mathrm{Y})\end{array}$ & & $\begin{array}{l}\text { New } \\
\text { Zealand } \\
(56 \% \mathrm{Y}) \\
\end{array}$ & \\
\hline 1912 & $\begin{array}{l}\text { Ohio + Colorado }(\mathrm{W}) \\
+ \text { Arkansas }(45 \% \mathrm{Y}) \\
\text { W. Virginia. }(69 \% \mathrm{Y}) \\
\end{array}$ & & & \\
\hline 1914 & Arizona + Colorado + Oregon & & New & \\
\hline
\end{tabular}




\begin{tabular}{|c|c|c|c|c|}
\hline & $\begin{array}{l}\text { +Virginia +Washington } \\
\text { (D);California + Ohio (W) }\end{array}$ & & $\begin{array}{l}\text { Zealand } \\
(49 \% \mathrm{Y})\end{array}$ & \\
\hline 1915 & S. Carolina (D), Ohio (W) & Alberta & & \\
\hline 1916 & $\begin{array}{l}\text { Oregon }+ \text { Washington + Alaska+ } \\
\text { Colorado + Arkansas +Idaho + } \\
\text { Michigan +Montana + Nebraska } \\
+ \text { S. Dakota (D); } \\
\text { California + Vermont + Missouri } \\
\text { (W) }\end{array}$ & & & \\
\hline 1917 & $\begin{array}{l}\text { N. Mexico + P. Rico (D) } \\
\text { Iowa + Ohio (W) }\end{array}$ & & & \\
\hline 1918 & $\begin{array}{l}\text { Wash + Florida + Minnesota } \\
+ \text { Utah + Wyoming + Nevada }+ \\
\text { Ohio (D); California + Missouri } \\
\text { (W) }\end{array}$ & & & \\
\hline 1919 & & $\begin{array}{l}\text { Ontario ( } \mathrm{Y} \text { and } \mathrm{N} \text { to } \\
\mathrm{SOE} \text { ) }\end{array}$ & $\begin{array}{l}\text { New } \\
\text { Zealand } \\
(50 \text { and } 49 \\
\% \mathrm{Y})^{*}\end{array}$ & \\
\hline 1920 & & $\begin{array}{l}\mathrm{BC}(\mathrm{N} \text { and } \mathrm{Y} \text { to } \\
\mathrm{SOE})\end{array}$ & & \\
\hline 1922 & & & $\begin{array}{l}\text { New } \\
\text { Zealand } \\
(49 \% \mathrm{Y} \\
\text { and } 6 \% \\
\text { SOE) }\end{array}$ & \\
\hline 1923 & & $\begin{array}{l}\text { Alberta ( } \mathrm{N} \text { and } \mathrm{Y} \text { to } \\
\text { SOE) }\end{array}$ & & \\
\hline 1924 & & $\begin{array}{l}\text { Ontario ( } \mathrm{Y} \text { and } \mathrm{N} \text { to } \\
\mathrm{SOE} \text { ) }\end{array}$ & & \\
\hline 1925 & & Saskatchewan & $\begin{array}{l}\text { New } \\
\text { Zealand } \\
(47 \% \mathrm{Y} \\
\text { and } \\
8 \% \text { SOE })\end{array}$ & $\begin{array}{l}\text { West } \\
\text { Australia } \\
(35 \% \mathrm{Y})\end{array}$ \\
\hline 1928 & & & $\begin{array}{l}\text { New } \\
\text { Zealand } \\
(41 \% \mathrm{Y} \\
\text { and } \\
9 \% \mathrm{SOE})\end{array}$ & $\begin{array}{l}\text { New South } \\
\text { Wales } \\
(28 \% \mathrm{Y})\end{array}$ \\
\hline 1930 & & & & $\begin{array}{l}\text { Victoria } \\
(43 \% \mathrm{Y}) \\
\end{array}$ \\
\hline
\end{tabular}

Notes: $\quad(D)=$ dry, a majority voting for prohibition; $(\mathrm{W})=$ wet, a majority voting against it; $\% \mathrm{Y}=$ proportion of votes for prohibition; $\mathrm{SOE}=$ state-owned enterprise for the sales of alcohol;

*: in that year 1919, New Zealand took 2 referendums (both with soldiers abroad voting): the first in April asking for or against prohibition with compensation; 
the second in December offering the choice between the statu quo, prohibition or state ownership and control.

Sources: For the U.S., 1880-1890: Szymanski (2003:138); 1900-1918: Blocker (1976: 237-238); results for some of those referendums from Hayler (1913: 275-294); To complete with Cherrington (ASL data). For Canada, Hayler (1913: 254-266) and Hose (1928: 108-109). For New Zealand, Butler and Ranney (1978: 236237) and New Zealand Yearbooks, 1911, 1915, 1920, 1922, 1927, 1930. For Australia, Butler and Ranney (1978: 125), Australia Yearbook 1928 for West Australia, Harkness E.B.'s report 1928 (2nd session) to the Legislative Assembly of New South Wales for N.S. Wales and the Victorian Government Gazette, April 24 1930, p. 1304 for Victoria.

TABLE 5

State and Provincial Prohibition in US and Canada

\begin{tabular}{|ll|}
\hline Canada & \\
Prince Edward Island & $1907-1948$ \\
Nova Scotia & $1916-1929$ \\
Saskatchewan & $1916-1925$ \\
Alberta & $1916-1924$ \\
Manitoba & $1916-1924$ \\
Ontario & $1916-1923$ \\
New Brunswick & $1917-1927$ \\
British Columbia & $1917-1921$ \\
Quebec & $1918-1919$ \\
\hline
\end{tabular}

Source: $\quad$ Smart and Ogborne (1996:49)

\begin{tabular}{||lll||}
\hline United States & & \\
Adopting States & Year & Non-Adopting States \\
\hline \hline Maine & 1851 & California \\
Kansas & 1880 & Connecticut \\
North Dakota & 1889 & Delaware \\
Georgia & 1907 & Illinois \\
Oklahoma & 1907 & Louisiana \\
Mississippi & 1908 & Maryland \\
North Carolina & 1908 & Massachusetts \\
Tennessee & 1909 & Minnesota \\
West Virginia & 1912 & Missouri \\
Virginia & 1914 & New Jersey \\
Oregon & 1914 & New York \\
Washington & 1914 & Pennsylvania \\
Colorado & 1914 & Rhode Island \\
Arizona & 1914 & Vermont \\
\hline \hline
\end{tabular}




\begin{tabular}{|lll||}
\hline Alabama & 1915 & Wisconsin \\
Arkansas & 1915 & \\
Iowa & 1915 & \\
Idaho & 1915 & \\
South Carolina & 1915 & \\
Montana & 1916 & \\
South Dakota & 1916 & \\
Michigan & 1916 & \\
Nebraska & 1916 & \\
Indiana & 1917 & \\
Utah & 1917 & \\
New Hampshire & 1917 & \\
New Mexico & 1917 & \\
Texas & 1918 & \\
Ohio & 1918 & \\
Wyoming & 1918 & \\
Florida & 1918 & \\
Nevada & 1918 & \\
Kentucky & 1919 & \\
\hline \hline
\end{tabular}

Source: Hersch and Netter (1989:58). Their source is Colvin (1926) work written for the Anti-Saloon League.

Winning Some, Losing Some: Prohibitionists Victorious in the US, Defeated in the rest of the Anglo-Saxon World, 1917-33

The US government adopted prohibition of alcohol in 1917 as a war measure. In December of the same year, the $18^{\text {th }}$ Amendment was proposed to the Congress, adopted with large majorities (282 to 128 in the House and 65 to 20 in the Senate) and declared ratified on January 19 1919. ${ }^{9}$ Enforcement was left to statute: the Volstead (National Prohibition Enforcement) Act was passed on October 281919 over the President Wilson's veto. In January $1^{\text {st }}, 1920$, the country turned «bone dry», that is manufacturing, transportation and

${ }^{9}$ Ratification requires a minimum of $3 / 4$ of the states, that is 36 on 48 . The $18^{\text {th }}$ Amendment was ratified by 45 states (Rhode Island, Connecticut never ratify it; New Jersey only in 1922). 
sale but not consumption nor home-fabrication of any intoxicating beverages defined as containing more than $0.5 \%$ alcohol were prohibited. ${ }^{10}$ Prohibition was to be repealed -the only amendment ever to be repealed- in 1933, again by a large majority in the Congress.

In Canada too, Word War I helped the temperance movement as prohibition became a patriotic act to save resources and to improve efficiency. All Canadian provinces adopted prohibition from 1915 or 1916 and the federal government adopted it in 1917 under the War Measures Act. At the end of 1919, the federal government let prohibition expire and control was returned to the provinces. All provinces except Quebec adopted prohibition until the mid twenties, but only retail sales were banned. ${ }^{11}$ In 1921, Quebec and British Columbia the two provinces where the prohibitionist fervor had always been milder-, created their Liquor Board, a state monopoly of alcohol sales. All the other provinces, with the exception of tiny Prince Edward Island which remained prohibitionist until 1948, followed between 1923 and 1927, the last one being Ontario.

In Australia, the temperance movement was finally able to get some state referendums on total prohibition in that period: Western Australia in 1925, New South Wales in 1928, Victoria in 1930. All were sharply defeated (see table 4). The only dry area in the country was the new capital of Australia, Canberra from 1915 to 1928. In New Zealand, the triennial referendums on prohibition saw the majority of 1911 declined to $49 \%$ and less at the end of

\footnotetext{
${ }^{10}$ It is outside the scope of our research but the real life experience of those 13 years of prohibition seem to have been quite a disaster, extensively documented: widespread illegal trade and networks, intensive smuggling through Canada and Mexico, control by the criminal underworld of Al Capone and the like, corruption and serious problems of enforcement.

${ }^{11}$ Leading to ludicrous situations where let's say an Ontarian had to order his alcohol from Quebec even if produced in Ontario since inter-provincial and international trade was legal but not intraprovincial trade ! Not to mention that exports of alcohol to the US by Canadian companies were legal until an agreement between the two countries was finally reached (in 1925 or 1929: to confirm).
} 
the 1920 s. The closest to come to total prohibition in the Australasian continent, the legacy was to be a highly restrictive environment. In both New Zealand and Australia, the main victory of the temperance movement turned out to be the 6 o'clock closing laws, lasting until well into the 1950s and 1960s. ${ }^{12}$

To sum up, in each of the four countries, there was an active and determinate Protestant-led temperance movement whose ultimate goal was total suppression of the liquor trade. Only in the U.S. did it succeed (even though Prohibition was to be repealed in 1933). How can we explain this outcome? Let us expose now in an informal way the model we wish to use to try to answer this question.

\section{A PUblic ChOICE Model}

To deal with the alcohol issue, a state can choose between five strategies:

1. total laissez-faire. To our knowledge, no modern state adopted it.

2. licensing (fees, control of numbers issued, etc) and taxing : Britain, Australia, New Zealand and many other countries.

3. «local option»: law allowing local units (counties, cities, townships) to ban sales of alcohol following a majority (simple or $3 / 5$ ) demanding it in periodic polls: typical in Anglo-Saxon countries such as the U.S., Britain, Canada, New Zealand and Australia (see tables 1, 2 and 3).

4. state monopoly of sales: in America, the Province of Quebec was the first to do this in 1921; all other Canadian provinces followed; Scandinavia also adopted it after its 1920s episodes of prohibition.

\footnotetext{
${ }^{12}$ It is only in 1967 that the 6 o'clock closing law was amended to 10 o'clock closing.
} 
5. prohibition of manufacture, importation, sale: national or regional: at a national level in the US (1920-1933), Russia, Finland, Iceland, Norway in the 1920s; regional prohibitions in the US before 1919 and in Canada (see table 5).

Total prohibition was certainly the most spectacular strategy but was not the most evident. To explain why some governments chose prohibition, we wish to use a political economy approach. We can think of the state as wishing to maximize three elements: net income; public order; and power, that is the electoral outcome. Financially, prohibition was undoubtedly a very costly choice for a government since high enforcement costs were incurred while an important source of fiscal revenues was eliminated. The social order motive is more debatable. Prohibitionists strongly believed that a society without alcohol would be a much more stable, peaceful, efficient and pleasant one. But in presence of a popular demand, enforcement of a ban proves very difficult if not impossible. Prohibition does not eradicate the banned product; it just drives it underground, giving rise to smuggling and illegal black markets. A gap is created between the legislations in the books and the reality. On top of these perverse effects, the credibility and legitimacy of the state may be undermined as these laws are largely disrespected. The US case has been thoroughly and frequently studied with a large consensus on the disastrous consequences of prohibition on law and order. ${ }^{13}$

This is why our hypothesis is that the political motive was the main driving force. In order to explain why the US -and to a lesser extent some parts of Canada- did choose prohibition and

${ }^{13}$ This was recognized long ago by great philosophers like Spinoza who wrote in the $17^{\text {th }}$ century: «All laws which can be broken without injustice to another person are regarded with derision and intensify the desires and lusts of men instead of restraining them; since we always strive for what is forbidden, and desire what is denied.... He who tries to determine everything by law will foment crime rather than lessen it». (pp. 433; 435). 
New Zealand and Australia did not, we must try to compare the strength and stakes of the supporters and opponents of prohibition in the four countries.

\section{The Drys}

The strongest the prohibitionist movement would be in a given society, the highest the probability of prohibition episodes, since the temperance reformers ideally preferred total prohibition, or at least partial or local bans as a stepping stone. They did not really like licensing and even less state monopoly as they felt that these two policies tended to legitimize the evil trade of alcohol. Their preferences were thus (referring to the five strategies enumerated above):

$$
\mathrm{S} 5>\mathrm{S} 3>\mathrm{S} 2>\mathrm{S} 4>\mathrm{S} 1
$$

What determines the strength of the prohibitionist movement in a given society? A number of potential factors to explore can be drawn from the historical and sociological literature on the US case. The first is religion. The temperance movement was Protestant-based, especially on the evangelical denominations (Methodists, Presbyterians, Baptists, Congregationalists). Putting aside the considerable controversy on their motivations, there is a consensus that these religious groups were the spearhead of the temperance fight against drinking. ${ }^{14}$ This was the case in the four countries of our concern. However, the religious landscape showed important differences between the four. In the U.S., evangelicalism dominated Protestantism (46\% of the Church-goers as compared to $30 \%$ of the population in

\footnotetext{
${ }^{14}$ The temperance movement has been perceived as people anxious to save souls by some or their middle-class status (by others following the notorious Gusfield 1963's thesis), as conservative unable to confront modernity (Hofstadter (1955) or as progressive fighting to transform modern society (for instance, Timberlake (1963) or Tyrrell (1991). The jury is still out.
} 
Canada and New Zealand and 20\% in Australia). ${ }^{15}$ In Australia and in New Zealand, the Anglican Church represented a much higher proportion of the population (about $40 \%$ in the two countries in 1911 compared to $14 \%$ in Canada and less than 2\% in the U.S.). In Canada because of the significant proportion of French Canadians (30\% in 1911), the Catholics were $40 \%$ of the population in 1911. Both the Roman Catholic and the Anglican Churches were in favor of moderation instead of prohibition and mostly stayed away from the prohibitionist movements.

The second factor is the rural-urban opposition. For a long time following Hofstadter (1955), the temperance movement was seen as the ultimate rural grassroots America's attack upon the big cities full of sin and foreigners. That it was a rural movement has been challenged since by those who preferred to see it as a more complex middle-class Protestant movement with rural roots but far from absent in urban settings. The WASP middle-class disliked the «Un American» low class, low race» new immigrants from Eastern and Southern Europe filling the large cities. ${ }^{16}$ Although the four countries were immigrant societies with in each some $15-20 \%$ of the population foreign-born, the diversity of the immigrants' origins was much higher in the US. In Australia and New Zealand, more than $90 \%$ of the foreign-born population was of British origin. The heterogeneity factor would thus seem a plausible hypothesis for us to explain the US more restrictive anti-alcohol policies.

${ }^{15}$ Information on religious affiliation is different between the US and the three other countries. In Canada, Australia and New Zealand, this information is provided by the Census, thus self-reported and covering non-practising as well as practising people. In the US, the question is not asked in the Census and the only available information comes from the churches about their membership. In the 1906 Census of Religions, there was a total of 33 million people reported by the various denominations (on a total population of 72 million in 1900). Of these 33 millions, $46 \%$ were of Evangelical denominations.

${ }^{16}$ See Morone (2003:302-308); Martin (2002:150); Timberlake (1963:152); Gusfield (1963); Blocker (1976). 
Thirdly, women were on the forefront of the movement in the four countries. Intemperance was generally a male problem and more specifically a husband problem (Thornton (1991:48). Women tended to be much more prohibitionist than men. The temperance cause has been linked by many authors to women's suffrage. For instance, in the US, of the 15 states which adopted universal suffrage prior to 1917, only two (California and New York) did not have state prohibition. ${ }^{17}$ It was in New Zealand that women got first national suffrage in 1893. In Canada, women did not vote before 1920 in elections but they did vote in the national plebiscite on prohibition in 1898 .

Fourthly, another potential factor was the business support of the movement, particularly in the U.S. ${ }^{18}$ Scientific management and large Chandlerian enterprises reinforced the case against drinking. As one observer declared: «Alcohol must go. The thing that temperance fanatics have been unable to accomplish, that a political party has failed to do, that even religion has not been able to bring about, is shortly to come to pass. Efficiency demands it. Industry calls for it. This is a scientific generation, and we are willing to see things as they are.» ${ }^{19}$ John Rockefeller, Henry Ford and many others contributed money, speeches and interventions to the prohibitionist cause. Cherrington, one of the leaders of the ASL, recognized in 1916 prohibition's recent successes were largely «due to the fact that we had finally interested business men of large interest and large calibre in this movement and they

${ }^{17}$ Wyoming (1890), Colorado (1893), Utah and Idaho (1896), Washington (1910), California (1911), Arizona, Kansas and Oregon (1912), Montana and Nevada (1914), New York (1917), Michigan, Oklahoma, South Dakota (1918). In Hersch and Netter (1989:68).

${ }^{18}$ Rumbarger (1989) is the author who argued most forcefully that: «men of power and substance defined, directed, and controlled the movement for drink reform». He was a student of G. Kolko who was notorious for his leftist position that the reform and regulation movements in the US were captured by big business. In the case of prohibition, Rumbarger's thesis is plausible but remains unproven and it must be very hard to prove.

${ }^{19}$ Quoted in Timberlake (1963:72). 
gave liberally to see this thing through.» ${ }^{20}$ Timberlake (1963:80) stated that by the time of ratification, the bulk of American business had joined other middle class America in the crusade and that without their support, it might have failed to become law. This seems to have been much more important in the U.S. We have not found a word about this in any Canadian, Australian or New Zealand studies.

Finally, an idiosyncratic factor of the US society is the situation at the turn of the $20^{\text {th }}$ century in the South. Morone (2003:293) links temperance to disenfranchisement of the Black people. He argues that alcohol and fear of the danger that drunken Black men could impose on White women were powerful tools in the efforts of many Southern states to disenfranchise Blacks. Table 3 reveals clearly that the South led by far the movement in terms of results: a proportion of $87 \%$ of the population lived in dry areas by 1912 as compared to a national average of $49 \%$.

\section{The Wets}

The strongest the opponents to prohibition are in a given society, the highest the probability that governments would end up with less extreme alcohol policies than prohibition. This can take the form of licensing and taxing or even local option of the Australian mild limited type (see table 1). While not totally enthusiastic about state monopoly, it was for them preferable to prohibition, local, regional or national. The anti-prohibitionists ranking of the set of governmental strategies was almost totally opposite to the prohibitionists' one:

$$
\mathrm{S} 1>\mathrm{S} 2>\mathrm{S} 4>\mathrm{S} 3>\mathrm{S} 5
$$

\footnotetext{
${ }^{20}$ Quoted In Rumbarger (1989:182).
} 
Unsurprisingly, the more combative wets were to be found in all segments of the alcohol industry: brewers, distillers, retail traders. In the U.S., they were organized into powerful associations like the U.S. Brewers Association (1862) and the National Retail Liquor Dealers Association (1893) with very important financial resources. ${ }^{21}$ In Canada, the industry was also organized in associations and they may well have played a crucial role in the Canadian government decision to repeal wartime prohibition instead of following the American example. Their stake was higher than the domestic market as the US prohibition was a golden opportunity for the Canadian distillers and brewers.

Consumers of alcoholic beverages were a typical Olson latent unorganized group without much political power. Moreover, as Munger and Schaller (1997) argue, in the case of sumptuary laws, individuals may well have two sets of preferences: a genuine not really prohibitionist and an apparent public prohibitionist because they are ashamed.

Finally, as we saw above, Catholics and Anglicans found prohibition too extremist a measure. This component of the Wet camp was especially important in Canada in 1898 and perhaps in 1919 with the strong anti-prohibitionist stance of the Catholic French-Canadians (then $30 \%$ of the population).

\section{CONCLUSION}

${ }^{21}$ By the beginning of the $20^{\text {th }}$ century in the US, distilling industry was highly concentrated (two companies producing $85 \%$ of the output); brewing also but to a lesser extent. Saloons were by that time largely controlled by the brewers (70\% of them, estimated Timberlake (1963:104)). 
To sum up, to our question of why the US was more prohibitionist than Canada, New Zealand or Australia, the most plausible factors seem to be a larger proportion of the population belonging to evangelical religious denominations, a stronger involvement from the large business sector, a stronger scare of the «other» within a more heterogeneous society in the North and within a segregated society in the South and perhaps a more assertive women's movement.

In Canada, the presence of a significant anti prohibitionist French-Canadian component $(30 \%)$ and the context of the neighbour prohibition opening business for producers tip the balance toward less dry policies that one might have expected by looking at the strong Protestant evangelical temperance movement.

In Australia and in New Zealand, the highest proportion of Anglicans within the Protestant population and the more homogeneous society (98\% of foreign-born British), and perhaps less support and involvement from the business community could explain the much less dry outcome than in North America.

Finally, there were important differences in the legislative rules between the four countries. For instance, as ratification required $3 / 4$ of the states (and not of the population), it has been estimated that the $18^{\text {th }}$ Amendment had only some $31 \%$ of popular support. In contrast, in Australia and in New Zealand, the most frequent majority required for a referendum to pass was $3 / 5$.

The objective of this paper was to set the comparative historical picture in the four countries and to develop some conjectures on what can explain best the differences. Next step will be 
to more formally and quantitatively test our model. We will use as dependent variables referendum results for two main reasons: a conceptual and a pragmatic. As Blocker (1976) argues, referendums are the best indicator of the population prohibitionist sentiments and preferences as they are direct single-issue processes compared to a political party or representative platform. And on practical grounds, there were no bills on prohibition to analyze in Australia, New Zealand and only regional partial and minor ones in Canada. There are potentially some 60 to 70 referenda across seven countries. We have collected the data disaggregated by electoral districts for New Zealand, Australia, Canada, Sweden, Norway and Finland. We still have to get the US data.

And even more arduous will be to use as explanatory variables data drawn from national Censuses on socio-cultural characteristics such as religion, proportion of foreign-born, occupational structure, education and urbanization. Many difficulties are to be found in different units (Census and electoral), different variables available, different methodologies and the like. In spite of all this, we believe that the project should produce valuable insight on that very exciting topic, especially when approached from an international perspective. 


\section{REFERENCES}

Blocker J.S. and Tyrrell I.R. (2003), Alcohol and Temperance in Modern History: an International Encyclopedia. Santa Barbara, California: ABC-CLIO. Articles on Australia (75-79), New Zealand (453-456), Provincial Prohibition (Canada) (496499), Woman's Christian Temperance Union (Australia) (675-676), WCTU (Canada) (676-677), WCTU (United States) (679-681).

Blocker, J.S. (1989), American Temperance Movements: Cycles of Reform. Boston: Twayne.

Blocker, J.S. (1976), Retreat from Reform: The Prohibition Movement in the United States, 1890-1913 Westport, Connecticut: Greenwood Press.

Butler D. and Ranney A. (1978), Referendums. A Comparative Study of Practice and Theory. American Enterprise Institute.

Colvin, D.L. (1926), Prohibition in the United States. New York: George H. Doran Co.

Goff, B. and Anderson, G., "The Political Economy of Prohibition in the United States, 1919-1933», Social Science Quarterly (75: 2), 270-283.

Gusfield, J. (1963), Symbolic Crusade: Status Politics and the American Temperance Movement. Urbana: University of Illinois Press.

Hayler, Guy (1913), Prohibition Advance in All Lands. A Study of the Worldwide Character of the Drink Question. London: International Prohibition Confederation.

Hersch, P.L. and Netter J.M. (1989), «State Prohibition of Alcohol: An Application of Diffusion Analysis to Regulation», Research in Law and Economics (12), 55-70.

Hofstadter, R. (1955), The Age of Reform: From Bryan to F.D.R. New York: McGraw Hill.

Hose, R. E. (1928), Prohibition or Control? Canada's Experience with the Liquor Problem 1921-1927. Toronto: Longmans, Green and Co.

Kerr, K. A. (1985), Organized for Prohibition. New Haven: Yale University Press.

Martin, J.P. (2002), La vertu par la loi. La Prohibition aux États-Unis 1920-1933. Dijon : Éditions universitaires de Dijon, $2^{\mathrm{e}}$ édition.

Miron, J. A. (2001) «Alcohol Prohibition» in R. Whaples ed., EH.NET Encyclopedia, September 25.

Miron, J.A. and Zwiebel J. (1991), «Alcohol Consumption During Prohibition», American Economic Review 81 (2), 242-247.

Morone, J.A. (2003), Hellfire Nation. The Politics of Sin in American History. New Haven: Yale University Press. 
Munger, M. and Schaller, T. (1997), «The Prohibition-Repeal Amendments: A Natural Experiment in Interest Group Influence», Public Choice (90), 139-163.

Noel, J. (1995), Canada Dry. Temperance Crusades before Confederation. Toronto: University of Toronto Press.

Paulson, R. E. (1973), Women's Suffrage and Prohibition: A Comparative Study of Equality and Social Control. Illinois: Scott and Foresm.

Reeves W.P. (1902; 1969), State Experiments in Australia and New Zealand. Macmillan of Australia (first published in 1902).

Rorabaugh, W. J. (1979), The Alcoholic Republic: An American Tradition. New York: Oxford University Press.

Rumbarger, J.J. (1989), Profits, Power and Prohibition: Alcohol Reform and the Industrializing of America, 1800-1930. Albany: SUNY Press.

Smart, R.G. and Ogborne A.C. (1996), Northern Spirits. A Social History of Alcohol in Canada. Toronto: Addiction Research Foundation, $2^{\text {nd }}$ edition.

Spinoza, B. (1958), «Tractatus Politicus/Treatise on Politics» in The Political Works of Benedict de Spinoza, translated and edited by A.G. Wernham, Oxford Clarendon Press.

Szymanski, A.M. (2003), Pathways to Prohibition: Radicals, Moderates and Social Movement Outcomes. Durham, North Carolina: Duke University Press.

Thornton, M. (1991), The Economics of Prohibition. Salt Lake City: University of Utah Press.

Timberlake, J. (1963), Prohibition and the Progressive Movement 1900-1920. Harvard University Press.

Tyrrell, I.R. (1991), Woman's World/Woman's Empire: The Women Christian Temperance Union in International Perspective. Chapel Hill: University of North Carolina Press.

Wasserman I.M. (1989), «The Missouri Prohibition Referendum of 1918» in Social Science Quarterly, (70), 886-901.

Wasserman I.M. (1990), «Status Politics and Economic Class Interests: The 1918 Prohibition Referendum in California» in Sociological Quarterly (31), 475-484. 


\section{Governmental Documents}

Australia Yearbook 1928 and Census 1921

Canada, Census 1911, 1921

New Zealand, Census 1911, 1921 and Yearbooks, various years.

United States, Census 1910, 1920

United States, Census of Religions, 1906 


\section{Liste des cahiers de recherche publiés par les professeurs des H.E.C. 2003-2004}

\section{Institut d'économie appliquée}

IEA-03-01 GAGNÉ; ROBERT; LÉGER, PIERRE THOMAS. « Determinants of Physicians’ Decisions to Specialize »,29 pages.

IEA-03-02 DOSTIE, BENOIT. «Controlling for Demand Side Factors and Job Matching: Maximum Likelihood Estimates of the Returns to Seniority Using Matched Employer-Employee Data »,24 pages.

IEA-03-03 LAPOINTE, ALAIN. « La performance de Montréal et l'économie du savoir: un changement de politique s'impose », 35 pages.

IEA-03-04 NORMANDin, MICHEL; PhAneuf, LOUIS. « Monetary Policy Shocks: Testing Identification Conditions Under Time-Varying Conditional Volatility », 43 pages.

IEA-03-05 BOILEAU, MARTIN; NORMANDin, MiCHEL. « Dynamics of the Current Account and Interest Differentials », 38 pages.

IEA-03-06: NORMANDIN, MICHEL; ST-AMOUR, PASCAL. « Recursive Measures of Total Wealth and Portfolio Return », 10 pages.

IEA-03-07: DOSTIE, BENOIT; LÉGER, PIERRE THOMAS. « The Living Arrangement Dynamics of Sick, Elderly Individuals », 29 pages.

IEA-03-08: NORMANDIN, MICHEL. « Canadian and U.S. Financial Markets: Testing the International Integration Hypothesis under Time-Varying Conditional Volatility », 35 pages. 
IEA-04-01: LEACH, ANDREW. «Integrated Assessment of Climate Change Using an OLG Model », 34 pages.

IEA-04-02: LEACH, ANDREW. "SubGame, set and match. Identifying Incentive Response in a Tournament », 39 pages.

IEA-04-03: LEACH, ANDREW. « The Climate Change Learning Curve », 27 pages.

IEA-04-04: DOSTIE, BENOIT; VENCATACHELLUM, DÉSIRÉ. « Compulsory and Voluntary Remittances: Evidence from Child Domestic Workers in Tunisia », 46 pages.

IEA-04-05: RENGIFo, E.W.; ROMBOUTS, J.V.K. « Dynamic Optimal Portfolio in a VaR Framework », 33 pages.

IEA-04-06: DOSTIE, BENOIT; TRÉPANIER, MATHIEU. « Return to Computer Use and Organizational Practices of the Firm », 41 pages.

IEA-04-07: ALLARD, MARIE; LÉGER, PIERRE THOMAS; ROCHAIX, LISE. « Provider Competition in a Dynamic Setting » 32 pages

IEA-04-08: MAURICE N. MARCHON. «Perspectives économiques canadiennes dans un contexte international » 27 pages.

IEA-04-09: NORMANDIN, MICHEL. " The Current Account and the Interest Differential in Canada », 27 pages.

IEA-04-10 AZAM, JEAN-PAUL; GAUTHIER, BERNARD; GOYETTE, JONATHAN. « The Effect of Fiscal Policy and Corruption Control Mechanisms on Firm Growth and Social Welfare: Theory and Evidence », 45 pages. 